\title{
Incidence of Salmonella spp. in Different Animal Species and Meat Products in Ecuador During the Period 2009-2019
}

\author{
Favian Bayas-Morejon ${ }^{1 *}$ (D), Angelica Tigre ${ }^{1}$, Ivonne Aldaz ${ }^{2}$, Paulina Parra ${ }^{2}$, Evelyn \\ Ramos $^{3}$, Roberto Remache ${ }^{4}$ and Carolina Zamora ${ }^{4}$
}

${ }^{1}$ State University of Bolivar, Center for Biotechnology Research and Development, Faculty of Agricultural Sciences, Natural Resources and Environment, CP: 020150, Guaranda, Ecuador. ${ }^{2}$ Higher Polytechnic School of Chimborazo, CP: 060150, Riobamba-Ecuador. ${ }^{3}$ Capakñam, CP: 060150, Riobamba, Ecuador. ${ }^{4}$ Higher Technological Institute Federal Republic of Germany, CP: 060150, Riobamba, Ecuador.

\begin{abstract}
Salmonella is a gram-negative bacillus of the family Enterobacteraceae, is a pathogen of importance in public health. In Ecuador there is little information regarding this microorganism. So that the objective of this work was to determine the incidence of Salmonella spp. in the different animal species and meat products in through a documentary review. After the documentary study, have been registered a total of $\mathbf{1 6 8 6}$ cases of salmonellosis in Ecuador, with a greater presence in the provinces of the Sierra (927 cases), followed by the provinces of the coast (729 cases) and finally the Amazon region with 30 cases. At the provincial level, the highest number of cases of salmonellosis occurs in the province of Pichincha with 805 cases, while, the highest incidence values it is in the province of Sto. Domingo with $85 \%$ of incidence. In relation to the level of incidence, the coastal region presents higher average percentage value (38.34\%), the most part due to the presence of the pathogen in food, followed by the sierra (27.57), and Amazon region (22.23), however, in the Island region (Galapagos) no quantitative data was registered.

Keywords: Incidence, Salmonella, Ecuador, animal species, meat products.
\end{abstract}

*Correspondence: isba@doctor.upv.es; fbayas@ueb.edu.ec

(Received: 29 March 2019; accepted: 29 May 2019)

Citation: Favian Bayas-Morejon, Angelica Tigre, Ivonne Aldaz, Paulina Parra, Evelyn Ramos, Roberto Remache and Carolina Zamora, Incidence of Salmonella spp. in Different Animal Species and Meat Products in Ecuador During the Period 2009-2019, J Pure Appl Microbiol., 2019; 13(2):725-732. doi: 10.22207/JPAM.13.2.08

(c) The Author(s) 2019. Open Access. This article is distributed under the terms of the Creative Commons Attribution 4.0 International License which permits unrestricted use, sharing, distribution, and reproduction in any medium, provided you give appropriate credit to the original author(s) and the source, provide a link to the Creative Commons license, and indicate if changes were made. 


\section{INTRODUCTION}

The objective of this work was: to determine the incidence of the Salmonella spp. in the different animal species and meat products in Ecuador through the literature review in the period 2009-2019. Salmonella is a Gram-negative bacillus, belongs to the Enterobacteraceae family. Most of the serovarieties that have been isolated from human and from warm-blooded animals belong to the enteric subspecies (subspecies I) and usually, their name is related to the geographical location where they were isolated for the first time (Grigar et al., 2017; Scallan et al., 2011).

There are more than 2.500 serovars or serotypes of Salmonella, the great majority belongs to the subspecies I, here find Salmonella enteritidis and Salmonella typhimurium, which are the most frequent in our environment (Ellermeier and Slauch, 2006).

Epidemiology of Salmonellosis

According by Gyles et al. (2010), from the epidemiological point of view Salmonella spp. it can be classified into three groups:

a) Those that do not have a preference for any special host, so infect both human and animals. Most of the serovars responsible for salmonellosis are found in this group.

b) Those that infect only human: Salmonella typhi, Salmonella paratyphi A and Salmonella paratyphi $\mathrm{C}$ and that are transmitted directly or indirectly from one person to another.

c) Those adapted to a host in different animal species, such as S. sbortusovis in sheep; $S$. abortusequi in equines and $S$. gallinarum in birds.

Its wide distribution worldwide and other characteristics that make it resistant has caused a pandemic of Salmonella enteritidis, which first appeared in the eighties and is attributed to the contamination of eggs (Rodrigue et al., 1990). The number of Salmonella infections related to this serotype has been increasing over time. In 1995, there was $36 \%$ of Salmonella enteritidis in the world, compared to $65 \%$ in 2002 (Herikstad, et al., 2002).

The program WHO-Global Salmonella Survey confirmed that between 2000 and 2004 Salmonella enteric serovar enteritidis, was the most isolated in the world from human matrices; while, in animal samples, others are the Salmonella pathogens commonly founds (Yim et al., 2010).
Salmonella is a bacterium zoonotic that is transmitted through food and requires an adequate temperature for its development between 35 to $37^{\circ} \mathrm{C}$. Once in your host organism triggers its toxicity that causes damage to the intestinal mucosa and sometimes the condition extends to a blood level.

The clinical picture usually emerges between the first day to the third day after the contamination, generating discomfort in the individual and symptoms such as dysentery, hyperthermia, pain at the nasogastric level, headaches and uncommon vomiting. When the bacteria reach the bloodstream, the individual is at risk of septicemia, osteomyelitis and meningitis (De Cesare, 2018).

Develoiping Incidence of Salmonella spp. Present in the Costa or Litoral Region of Ecuador Esmeraldas

In a study in the province of Esmeraldas on the prevalence of Salmonella in poultry farms, none of the two farms surveyed tested positive for the Salmonella prevalence test (Casart et al., 2018).

\section{Los Rios}

According to the research of Galiano et al. (2011), in the data of the National Directorate of Epidemiological Surveillance (DNVE) of the Ministry of Public Health (MSP). It has been reported that in the province of Los Rios, there were 47 cases of infections due to Salmonella spp. probably due to the ingestion of contaminated meat products, of which 39 cases were found in the city of Babahoyo.

\section{Santo Domingo}

In this province, 25 cases of salmonellosis have been evidenced in meat products that are contaminated during the process of raising transporting the animals, as considered by Rodriguez Merchan and Silva (2017). So also, Sanchez Chugchilon (2016), in their research where the authors detected higher Salmonella incidence during the process of slaughtering chicken skin before chilling with $85 \%$ incidence and $50 \%$ during the blind process in transport, said pathogen showed resistance to Quinolones. Manabi

According to Rodriguez Merchan and Silva (2017), in the province of Manabi after microbiological analysis detected 15 cases of pigs 
Table 1. Taxonomic classification of the Salmonella genus

\begin{tabular}{|c|c|c|c|}
\hline \multirow[b]{2}{*}{ Author/s } & \multirow[b]{2}{*}{ year } & \multicolumn{2}{|l|}{ Salmonella } \\
\hline & & Specie & Origin \\
\hline Borman & 1957 & Salmonella arizonae & \\
\hline Le Minor & 1985 & Salmonella bongori & Gastrointestinal \\
\hline Smith & 1894 & Salmonella choleraesuis & Feces \\
\hline Borman & 1957 & $\begin{array}{l}\text { Salmonella choleraesuis } \\
\text { subsp. arizonae }\end{array}$ & Feces \\
\hline Le Minor & 1985 & $\begin{array}{l}\text { Salmonella choleraesuis } \\
\text { subsp. bongori }\end{array}$ & Feces \\
\hline Smith & 1894 & $\begin{array}{l}\text { Salmonella choleraesuis } \\
\text { subsp. choleraesuis }\end{array}$ & Feces \\
\hline Le Minor & 1985 & $\begin{array}{l}\text { Salmonella choleraesuis } \\
\text { subsp. diarizonae }\end{array}$ & Feces \\
\hline Le Minor & 1985 & $\begin{array}{l}\text { Salmonella choleraesuis } \\
\text { subsp. houtenae }\end{array}$ & Feces \\
\hline Le Minor & 1987 & $\begin{array}{l}\text { Salmonella choleraesuis } \\
\text { subsp. indica }\end{array}$ & Feces \\
\hline Le Minor & 1985 & $\begin{array}{l}\text { Salmonella choleraesuis } \\
\text { subsp. salamae }\end{array}$ & Feces \\
\hline $\begin{array}{l}\text { Kauffmann and } \\
\text { Edwards }\end{array}$ & 1952 & Salmonella enterica & Feces \\
\hline Borman & 1957 & $\begin{array}{l}\text { Salmonella enterica subsp. } \\
\text { arizonae }\end{array}$ & Gastrointestinal \\
\hline Le Minor & 1985 & $\begin{array}{l}\text { Salmonella enterica subsp. } \\
\text { bongori }\end{array}$ & Gastrointestinal \\
\hline Le Minor & 1985 & $\begin{array}{l}\text { Salmonella enterica subsp. } \\
\text { diarizonae }\end{array}$ & Gastrointestinal \\
\hline $\begin{array}{l}\text { Le Minor and } \\
\text { Popoff }\end{array}$ & 1987 & $\begin{array}{l}\text { Salmonella enterica subsp. } \\
\text { ent'rica }\end{array}$ & Gastrointestinal \\
\hline $\begin{array}{l}\text { Le Minor and } \\
\text { Popoff }\end{array}$ & 1987 & $\begin{array}{l}\text { Salmonella enterica subsp. } \\
\text { houtenae }\end{array}$ & Gastrointestinal \\
\hline $\begin{array}{l}\text { Le Minor and } \\
\text { Popoff }\end{array}$ & 1987 & $\begin{array}{l}\text { Salmonella enterica subsp. } \\
\text { indica }\end{array}$ & Gastrointestinal \\
\hline $\begin{array}{l}\text { Le Minor and } \\
\text { Popoff }\end{array}$ & 1987 & $\begin{array}{l}\text { Salmonella enterica subsp. } \\
\text { salamae }\end{array}$ & Gastrointestinal \\
\hline $\begin{array}{l}\text { Castellani and } \\
\text { Chalmers }\end{array}$ & 1919 & Salmonella enteriditis & Gastrointestinal \\
\hline Ezaki & 2000 & Salmonella paratyphi & Bowels and bloodstream \\
\hline Shelobolina & 2005 & Salmonella subterranea & \\
\hline Warren and Scott & 1930 & Salmonella typhi & Feces \\
\hline $\begin{array}{l}\text { Castellani and } \\
\text { Chalmers }\end{array}$ & 1919 & Salmonella typhimurium & Bowels \\
\hline
\end{tabular}

LPSN (2019)

infected with Salmonella, which had white spots in the lungs, liver and intestines. On the other hand, in another study carried out in a processing plant in the city of Manta by Lvia and Trujillo (2013), the authors randomly selected 50 samples of fresh gutted prickly pear and 25 contact surface samples, 150 pinchagua samples in the transport stage and 25 contact surface samples taken from the handlers in the fish market stage; of the total samples analyzed, 4 positive results were detected in the presence of Salmonella spp. on the contact surfaces. 


\section{Santa Elena}

In this province studies were found on the prevalence of Salmonella in meat products in Planning Area 4, where Santa Elena was included. The results showed that, in total, 518 cases were reported for the last morbidity profile in 2016 (Rodríguez Merchan and Silva, 2017).

Guayas

In the province of Guayas the incidence of Salmonella is very wide since 120 cases of salmonellosis were found according to the research developed by Cedeño (2015), mostly present in poultry, domestic animals, sheep, bovines, among others, are usually the main origin of the contagion of this disease because they are the entity that these bacteria use as a reservoir. On the other hand, in another study carried out by Casart et al. (2018), registered an incidence in poultry farms by $11.1 \%$. Also, in another study conducted by Plaza (2013), where he performed a microbiological analysis on cheeses that are sold in the city of Guayaquil, evidenced the presence of Salmonella spp. in $13.71 \%$ of the cheeses analyzed (8/51).

El Oro

Loayza (2011), carried out a study in the municipal market of the city of Piñas in the province of Oro, where they detected the presence of Salmonella in bovine meat by $66.66 \%$. On the other hand, in the study carried out by Casart et al. (2018), detected Salmonella in $16.70 \%$ of the samples analyzed.

Incidence of Salmonella spp. Present in the Sierra or Interandina Region

Carchi

In a study developed by Campoverde (2014), in Tulcan province of Carchi, where 17 stalls selling artisan sausages were evaluated, and the presence of Salmonella $30.6 \%$ were identified in chorizo and $25 \%$ in black pudding. In contrast to the results obtained in commercial brands of chorizo where the results were negative for Salmonella.

Imbabura

In a study developed by Sanchez (2016), in a total of 299 samples collected of which: 177 corresponded to raw materials, 10 to finished food, 17 to papers of transport of chickens of 1 day, 51 to farms, 4 to blind, 20 to skin of chickens before and 20 after of the chiller. Resulting in 60
Table 2. Cases Susceptible to Avian Infectious Laryngotracheitis in 2014

\begin{tabular}{lccc}
\hline Month & Province & Susceptible & Cases \\
\hline January & Cotopaxi & 127974 & 25 \\
February & Cotopaxi & 10500 & 25 \\
\hline
\end{tabular}

Table 3. Summary of Incidence media values of Salmonella spp. in Ecuador by Regions

\begin{tabular}{lc}
\hline Region & Incidence (\%) \\
\hline Coast & 38.34 \\
Sierra region & 27.57 \\
Amazon region & 22.23 \\
Island region & - \\
\hline
\end{tabular}

Table 4. Cases and Incidence of Salmonella genus for provinces in Ecuador

\begin{tabular}{|c|c|c|c|}
\hline Provinces & Cases & Incidence & Year \\
\hline Los Rios & 47 & 0.00 & 2011 \\
\hline Sto Domingo & 25 & 85.00 & 2009; 2010 \\
\hline Manabi & 19 & 0.00 & $2013 ; 2017$ \\
\hline Sta Elena & 518 & 0.00 & 2017 \\
\hline Guayas & 120 & 12.35 & $\begin{array}{c}\text { 2015; 2017; } \\
2018\end{array}$ \\
\hline El Oro & 0 & 41.00 & $2011 ; 2018$ \\
\hline Carchi & 0 & 27.80 & 2014 \\
\hline Imbabura & 60 & 20.00 & $2016 ; 2018$ \\
\hline Pichincha & 805 & 28.36 & $\begin{array}{l}2012 ; 2015 ; \\
2016 ; 2018\end{array}$ \\
\hline Cotopaxi & 50 & 0.00 & 2014 \\
\hline Tungurahua & 2 & 9.75 & $2013 ; 2018$ \\
\hline Bolivar & 0 & 35.67 & $\begin{array}{c}2014 ; 2015 ; \\
2018\end{array}$ \\
\hline Loja & 0 & 42.50 & $2014 ; 2018$ \\
\hline Cañar & 10 & 43.10 & 2016 \\
\hline $\begin{array}{l}\text { Morona } \\
\text { Santiago }\end{array}$ & 8 & 0.00 & 2009 \\
\hline Napo & 0 & 29.15 & $2015 ; 2018$ \\
\hline Pastaza & 22 & 15.30 & 2018 \\
\hline Total & 1686 & & \\
\hline
\end{tabular}

positive samples for Salmonella after molecular analysis.

On the other hand, in the study by Casart et al. (2018), $42.9 \%$ of the samples analyzed were positive for Salmonella.

Pichincha

In 2011, 805 cases of salmonellosis were reported in the province of Pichincha, without 
informing the origin (Direccion Provincial de Salud de Pichincha, 2012). On the other hand, Villagomez et al. (2015), carried out a field work in the poultry slaughtering industrial plant, located in the province of Pichincha, in the sector of Calderon belonging to the Quito. At the end of the sampling, of the 25 skin pools processed and analyzed during this investigation, $20(80 \%)$ were positive for Salmonella spp. In the same way in the investigation, on fecal content of poultry slaughtered in industrial slaughterhouses in Pichincha has reported isolates of Salmonella spp. in $8.45 \%(n=142)$ (Villagomez, 2015). So also, in the study by Casart et al. (2018), obtained a prevalence of Salmonella in $10 \%$ of the samples analyzed.

In another study conducted by VinuezaBurgos et al. (2016), indicated that $15.9 \%$ of the batches in the province of Pichincha are Salmonella positive.

\section{Cotopaxy}

Toaquiza (2017), conducted a study in 9 farms in the province of Cotopaxi in 2015, where it was confirmed that there were no outbreaks of salmonellosis.

In addition, according to the OIE, in its 2014 World Animal Health Information System, a total number of 278.444 birds were reported to have outbreaks of Avian Infectious Laryngotracheitis and Avian Mycoplasmosis in January and February, as detailed in Table 2.

Tungurahua

According to Rodriguez (2013), in his research, they selected 450 chicken eggs, distributed in 150 samples from 50 poultry farms. Of the total samples processed and analyzed, a prevalence of Salmonella enteritidis of $1.3 \%$ $(2 / 150)$ was found. These samples were confirmed by biochemical tests and serotyping. So also, in the study by Casart et al. (2018), obtained a prevalence of Salmonella in $18.2 \%$ of the samples analyzed. Chimborazo

In a study conducted by Jara (2016), he investigates the presence of microorganisms in the ground meat sold in the city of Riobamba, detecting for Salmonella presence / $25 \mathrm{~g}$.

Bolivar

An investigation was carried out to determine the incidence of Salmonella types in chicken eggs sold in the markets of Guaranda,
Chimbo and San Miguel, 297 samples were analyzed in 99 eggs, being examined both in shell and content (yolk-clara), it was determined that the incidence of Salmonella types in Creole chicken eggs is low (Solano-Buñay, 2015). On the other hand, our research group carried out a study of susceptibility to natural extracts in 32 Salmonella isolates obtained from 100 consumer types of meat (beef, pork and chicken) in the city of Guaranda (Bayas-Morejon et al., 2018).

Loja

An investigation was carried out in the community of Oñacapac, where the inhabitants are $100 \%$ indigenous, in the Province of Loja, canton Saraguro. The objective of the research work was to determine the causes of mortality in guinea pigs, for which observations were made of the characteristic symptomatology present in the guinea pigs and the microbiological analysis, obtaining a prevalence of $35 \%$ (Guaman, 2014). So also, in the study conducted by Casart et al. (2018), obtained a prevalence of Salmonella in $50 \%$ of the samples analyzed.

\section{Cañar}

According to Vargas (2016), the main source of infection or transmission of salmonellosis is found in meat products derived from pigs, since 10 cases of salmonellosis were detected in pigs. This result shows that sales of pork are an important reservoir of this bacterium. and other products of porcine origin should be taken into account as a potential source of Salmonella infection. The results are mainly $43.1 \%$ of the total sales of pigs where it was used in the ELISA techniques that are commonly used for the serological diagnosis of porcine salmonellosis.

\section{Azuay}

Of some studies conduced on foods of meat products in the province of Azuay, the presence of Salmonella has not been detected (Paucar and Tenecora, 2013)

Incidence of Salmonella spp. Present in the Amazon Region

\section{Sucumbios}

No published data have been registered

\section{Morona Santiago}

In the canton Pablo VI, a study was carried out on 10 farms producing milk in the area, in which it was determined that 8 of them were 
infected with Salmonella, through the tests taken on the milk, a very acute degree of Salmonella was determined in each one of the farms putting the milk-producing area in quarantine and under the protection of treatments for animals (Pelaez, 2009).

Napo

In the research carried out by Tena (2015), of the samples obtained in a free trade show, $75 \%$ resulted in a negative presence of Salmonella while $25 \%$ turned out to be positive out of a total of 12 samples taken. Concluding that the main pork focusses of infection for salmonellosis. So also, in the study by Casart et al. (2018), obtained a prevalence of Salmonella in $33.3 \%$ of the samples analyzed.

Pastaza

In a study conducted by Egas (2018), Salmonella was identified in $15.3 \%$ ( $n=22 / 144$ ) of the samples analyzed. The only serotype identified was $S$. Infantis ( $=5$ ).

Orellana

No published data have been registered Zamora

In the canton Pangui, a case of the loss of an establishment of broiler birds was detected where Salmonella spp. contamination had occurred in balanced feed, infecting the net population, resulting in the disease known as typhoid. The Agrocalidad department performed serological tests on the feed and on a batch of animals to determine the infection taken and the reaction of the batch to the same resulting in the involuntary slaughter of the animals in the growth stage.

Incidence Salmonella spp. Present in Galapagos

Aquatic turtles or sea turtles and iguanas are frequently carriers of Salmonella, a bacterium that is lodged in the digestive tract of these animals and can be transmitted to humans with the danger that they will contract the disease of salmonellosis Franco et al. (2011).

\section{Analysis of Data}

According to the data investigated, have been registered a total of 1686 cases of salmonellosis in Ecuador, with a greater presence in the provinces of the Sierra (927 cases, followed by the provinces of the coast ( 729 cases) and finally the Amazon region with 30 cases.

At the provincial level, it can be seen that the highest number of cases of salmonellosis occurs in the province of Pichincha, while in the case of average incidence values it is in the province of Sto. Domingo, Table 4.

In relation to the level of incidence, the coastal region presents higher average percentage value the most part due to the presence of the pathogen in food, followed by the Sierra, and Amazon region, however, in the Island region (Galapagos) no quantitative data was registered. (Table 3).

The figure below shows the level of incidence by year of Salmonella in meat products

The figure shows that there is a higher incidence of Salmonella in relation to the number of studies conducted were in the years 2009, 2011 and 2018 with average data that exceed $40 \%$ of samples recorded.

\section{Incidence in Ecuador by year}
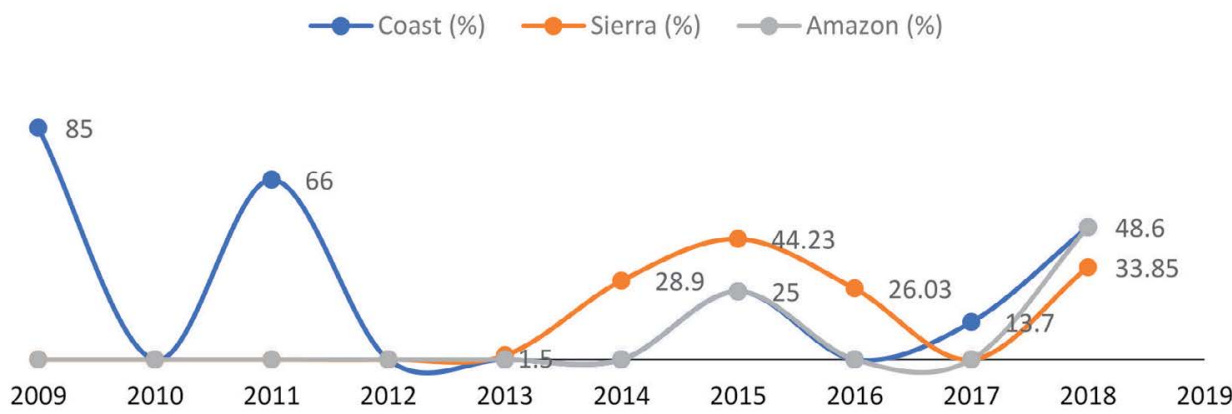

Fig. 1. Salmonella incidence level by year 


\section{CONCLUSION}

With more than 1600 registered cases in Ecuador, where the Costa region presents the highest average for the presence of Salmonella and is generally related to food contamination, we can consider that environmental and sanitary conditions (overcrowding of animals in farm), may influence direct on the pathogen incidence.

\section{ACKNOWLEDGEMENTS}

We would like to express our heartfelt thanks to Professor Dr. Riveliño Ramón-Curay for providing information for the development of this revision work, Thanks to the State University of Bolivar, and to the debt exchange program Ecuador - Spain, for the received support.

\section{CONFLICT OF INTEREST}

The authors declare that there is no conflict of interest.

\section{AUTHORS' CONTRIBUTION}

$F B, A T, I A, P P$ drafted the manuscript. AT, $I A$ and $P P$ gathered information from the literature about data from the provinces of the coast, sierra and the amazon región respectively. FB compiled information from the literature, and designed the figures and tables. EM and RR supervised and reviewed the manuscript. $C Z$ designed and did the final formatting of the figures and tables.

\section{FUNDING}

None.

\section{DATA AVAILABILITY}

All datasets generated or analyzed during this study are included in the manuscript and/or the Supplementary Files.

\section{ETHICS STATEMENT}

This article does not contain any studies with human participants or animals performed by any of the authors.

\section{REFERENCES}

1. Bayas-Morejon F., Tigre-Leon A., Ruilova M., Ramon R. Actividad antibacteriana de extractos de Physalis peruviana L. contra cepas de Salmonella spp. aisladas de carnes. XXI Congreso Nacional de Microbiologia de
Ios Alimentos., 2018; Sesion 3A Productos carnicos, 172-173.

2. Campoverde A. Evaluacion microbioligica de Escherichia coli y Salmonella en embutidos artesanales (chorizo y morcilla) expendidos en los mercados de la ciudad de Tulcan. Repositorio del centro de investigacion, Transferencia Tecnologica y Emprendimiento (CITTE)., 2014; Articulo Investigacion Codigo, (Cl-10-2014), 1-12.

3. Casart Y., Diaz Martinez A.N., Falconi M., Koch A., Proaño-Perez F., Santiana I. Salmonella prevalence in poultry farms of Ecuador and serotype identification based on multiplex PCR system. Revista Cientifica, FVC-LUZ., 2018; XXVIII, 3: 227-234.

4. Cedeño P. Casos de Salmonella en la provincia de Guayas. 2015

5. De Cesare A. Salmonella in Foods: A Reemerging Problem. Adv. Food Nutr. Res., 2018; 86: 137-179. doi: 10.1016/bs.afnr.2018.02.007.

6. Direccion Provincial de Salud de Pichincha. "Provincial Health Office of Pichincha". 2012.

7. Egas D. Aislamiento e identificacion de Salmonella, Escherichia coli productor de $\beta$-lactamasas de espectro extendido (BLEE) en granjas avocolas de reproductoras pesadas en las provincias de Napo y Pastaza, Ecuador. Titulo de Magister en Produccion y Sanidad Avicola. Universidad Central del Ecuador., 2018; pp. 98.

8. Ellermeier C.D., Slauch J.M. The Genus Salmonella. In: Dworkin M., Falkow S., Rosenberg E, Schleifer $\mathrm{KH}$, Stackebrandt E. (eds) The Prokaryotes. Springer., 2006; New York, NY. https://doi.org/10.1007/0-38730746-X_7.

9. Franco A., Hendriksen R.S., Lorenzetti S., Onorati R., Gentile G., Dell'Omo G., et al. Characterization of Salmonella Occurring at High Prevalence in a Population of the Land Iguana Conolophus subcristatus in Galapagos Islands, Ecuador. PLoS ONE., 2011; 8: e23147.

10. Galiano L. Determinacion de Salmonella sp. en la parte interna y externa de huevos de gallina procedentes de granjas reproductoras". Trabajo de titulacion previo a optar el titulo de Quimica Biologa. Universidad de San Carlos de Guatemala., 2011; 1-45.

11. Grigar M.K., Cummings K.J., Rankin S.C. Prevalence of Salmonella among waterfowl along the Texas Gulf coast. Zoonoses Public Health., 2017; 00: 1-4.

12. Guaman M. Determinacion del genero y especie de Salmonella en cuyes mestizos en diferentes sistemas de crianza en la comunidad de Oñacapac del canton Saraguro. Trabajo de Titulacion de grado en Medicina veterinaria y Zootecnia, Universidad Polit'cnica Salesiana, Cuenca., 2014; 110.

13. Gyles C., Prescott J., Songer G., Thoen C. Pathogenesis of bacterial infections in animals. Cuarta-Edicion. lowa: Editorial Office. 2010 Libro-e.

14. Herikstad H., Motarjemi Y., Tauxe R.V. Salmonella surveillance: a global survey of public health cero typing., 2002. URL: http://www.ncbi.nlm.nih.gov/pmc/ articles/PMC2869853/?tool=pub med.

15. Jara $\mathrm{H}$. Analisis microbiologico de las carnes molidas expendidas en el mercado la Condamine de la ciudad de Riobamba. Trabajo de Titulacion de grado en 
Quomica y Farmacias, Escuela Superior Politicnica de Chimborazo. Riobamba., 2016; 99.

16. Loayza S. Control de la calidad de carne de bovino en el mercado municipal en la ciudad de Piñas provincia del Oro. Trabajo de Titulacion de grado en Medicina Veterinaria y Zootecnia, Universidad Nacional de Loja., 2011; 144.

17. LPSN. (List of Prokaryotic names with Standing in Nomenclarutre). Especies del genero Salmonella reconocidas., 2018; http://www.bacterio.net/index. html

18. Lvia V. and Trujillo D. determinacion de carga bacteriana (Salmonella spp) en pinchagua (Opisthonema spp) en cuatro etapas de proceso. Trabajo de Titulacion en el grado de Bioquimico, Universidad Laica Eloy Alfaro de Manabi., 2013; 113.

19. Paucar L. and Tenecora J. Determinaciqn de Salmonella spp. en materia prima carnica de la empresa Italimentos mediante la tecnica visual inmunoensayo TECRA Salmonella via. Trabajo de Titulacion de grado en Bioquimico farmaceutico, Universidad de Cuenca., 2013; 93.

20. Pelaez D. Evaluacion de la calidad fisico - quimico, microbiologico y organoliptico de la leche del cant $\mathrm{n}$ Pablo Sexto incluyendo buenas practicas agrocolas (BPA). Trabajo de Titulacion de grado en Ingenieria en Industrias Pecuarias, Escuela Superior Politecnica de Chimborazo. Riobamba., 2009; 19.

21. Plaza L.A. Analisis Microbiologico en Quesos Frescos que se Expenden en Supermercados de la Ciudad de Guayaquil, Determinando la Presencia o Ausencia de Listeria y Salmonella. Trabajo de Titulacion de grado en Alimentos, Superior Politecnica del Litoral., 2013; 241.

22. Rodrigue D., Tauxe R., Rowe B. International increase in Salmonella enteritidis, a new pandemic. Epidemiol Infect., 1990; 105 1: 21-7.

23. Rodriguez R. Determinacion de la prevalencia de enterobacterias del genero Salmonella spp. en huevos frescos de gallina de empresas avicolas de la provincia del Tungurahua. Titulo de Medico Veterinario y Zootecnista Grado Academico de Medico Veterinario y Zootecnista, Universidad Central del Ecuador., 2013; 59.

24. Rodriguez Merchan K. and Silva B. Salmonella en productos carnicos en la Zona de Planificacion 4. Trabajo de Titulacion, Repositorio Universidad Estatal de Milagro., 2017.
25. Sanchez Chugchilan X. Identificacion molecular de Salmonella spp. en un sistema integrado de pollos de engorde. Trabajo de Titulacion de grado en Medicina Veterinaria y Zootecnia, Universidad Central del Ecuador., 2016; 88.

26. Sanchez X. Identificacion molecular de Salmonella spp., en un sistema integrado de produccion de pollos de engorde. Trabajo de Titulacion de grado en Medicina Veterinaria y Zootecnia, Universidad Central del Ecuador., 2016; 88.

27. Scallan E., Hoekstra R., Angulo F., Tauxe R., Widdowson M., Roy S., Griffin P. 2011. Foodborne illness acquired in the United States-major pathogens, Emerg. Infect. Dis., 2011; 17: 7-15.

28. Solano-Buñay S. Incidencia de los tipos de Salmonella en los huevos de gallina criolla que se expenden en los mercados de Guaranda, Chimbo y San Miguel. Tesis de grado en Medicina Veterinaria y Zootecnia.Universidad Estatal de Bolivar., 2015.

29. Tena S. Determinacion de Salmonella spp en la cadena de comercializacion de carnes de cerdos faenados en la ciudad del Tena. 2015.

30. Toaquiza A. Enfermedades infecciosas y parasitarias presentes en aves en la provincia de Cotopaxi. Totulo de Medico Veterinario, Universidad Tecnica del Cotopaxi., 2017; 78

31. Vargas J. Salmonelosis porcina en la feria ubicada en la ciudad de Azogues. Poster Agrocalidad., 2015; 48. http://www.agrocalidad.gob.ec/wp-content/uploads/ downloads/2014/04/FOLLETO-RECONOCIENDO\%20 LA-PPC-opt.pdf

32. Villagomez A. Aislamiento y serotipificacion de Salmonella enteritidis, Typhimurium, E Infantis en carcasas de pollo destinadas para consumo humano en un camal industrializado de la provincia de Pichincha. Trabajo de Titulacion de grado en Medicina Veterinaria y Zootecnia, Universidad Central del Ecuador., 2015; 94.

33. Vinueza-Burgos C., Cevallos M., Ron Garrido L., Bertrand S., De Zutter L. 2016. Prevalence and Diversity of Salmonella Serotypes in Ecuadorian Broilers at Slaughter Age. PLoSONE., 2016; 11 7: e0159567. doi:10.1371/journal.pone.015956

34. Yim L., Betancor L., Martinez A., Giossa G., Bryant C., Maskell D. and Chabalgoity J. Differential phenotypic diversity among epidemic-spanning Salmonella enterica serovar enteritidis isolates from humans or animals. Appl. Environ. Microbiol., 2010; 76 20: 681220. 